\title{
Diatoms from the Colombian and Peruvian Amazon: the Genera Encyonema, Encyonopsis and Gomphonema (Cymbellales: Bacillariophyceae)
}

Amelia A. Vouilloud $^{1}$, Silvia E. Sala ${ }^{1}$, Marcela Núñez Avellaneda ${ }^{2} \&$ Santiago R. Duque $^{3}$

1. Departamento Científico Ficología. Facultad de Ciencias Naturales y Museo. Paseo del Bosque s/n. 1900. La Plata. Argentina; avouilloud@yahoo.com.ar; sesala@museo.fcnym.unlp.edu.ar

2. Instituto Amazónico de Investigaciones Científicas (SINCHI). Avenida Vásquez Cobo entre calles 15 y 16. Leticia, Amazonas. Colombia; mnunez@sinchi.org.co

3. Instituto Amazónico de Investigaciones (Imani), Sede Amazonia Universidad Nacional de Colombia. Kilómetro 2 vía Tarapacá. Leticia, Amazonas. Colombia; srduquee@unal.edu.co

Received 13-III-2009. Corrected 14-VII-2009. Accepted 14-VIII-2009.

\begin{abstract}
Diatoms from the Colombian and Peruvian Amazon: the Genera Encyonema, Encyonopsis and Gomphonema (Cymbellales, Bacillariophyceae). The diatom flora of the Colombian and Peruvian Amazon is far less studied than the flora of the Brazilian sector of the basin. Here we present results related to the genera Encyonema, Encyonopsis and Gomphonema. Plankton and periphyton samples were collected in lotic and lentic waterbodies from the Amazonian-Andean region, the Amazon River, Japurá River and Porvenir River basins during 1993, 1994, 2001 and 2003. At each sampling station pH, temperature, water transparency and conductivity were registered. Samples were analyzed with phase contrast microscope (LM) and scanning electron microscope (SEM). Ten taxa are new records for the area; Encyonema for the Peruvian and Colombian Amazon and Encyonopsis for the Colombian Sector. Encyonema neogracile var. tenuipunctatum, E. vulgare, Encyonopsis frequentis, Gomphonema augur var. sphaerophorum and G. contraturris are recorded for the first time in Colombia; Encyonema venezolanum and G. neoapiculatum in Colombia and Peru and the latter also for Amazonia. E. angustecapitatum was mentioned in Colombia before at a pond located at $3000 \mathrm{~m}$ asl. We describe a new species from Porvenir River, Amazonas, Colombia: Encyonema amazonianum. Rev. Biol. Trop. 58 (1): 45-62. Epub 2010 March 01.
\end{abstract}

Key words: diatoms, Encyonema, Encyonopsis, Gomphonema, Amazonia.

Information about diatom flora of South America is incomplete and needs careful revision on the basis of modern analytical tools. Although most diatom researchers assume that freshwater diatoms are widespread, the cosmopolitan paradigm is, however, in conflict with observations (Kociolek \& Spaulding 2000). These authors pointed out that regional studies in which a concerted effort to determine species with a consistent taxonomy provide a way to examine cosmopolitism. They also mentioned several examples of morphological detailed studies which demonstrated that taxa may be misidentified or erroneously described as having disjoint distribution. Part of this problem can be attributed to the use of bibliography from Central Europe where diatom studies have great development. Logares (2006) points out the same ideas for other groups of microorganisms.

The most recent and general analyses of South American diatom flora were held by Metzeltin \& Lange-Bertalot $(1998,2007)$ in tropical areas, by Rumrich et al. (2000) in the Andes from Venezuela to Tierra del Fuego and Metzeltin et al. (2005) from temperate zones. Metzeltin \& Lange-Bertalot (1998) pointed out that in warm or cold regions of South America 
there is a great number of species that are cosmopolitan or typical of temperate climatic zones, while in the tropical regions the flora is completely different, with exception of the areas with a high antropic influence, and that there are many endemic taxa. The observations of Rumrich et al. (2000) confirm these ideas with exception of many endemic taxa of high altitudes. These approaches are of great interest as a starting point of modern floristic studies in South America, but regional studies are still necessary for testing them because these analyses were based in a limited number of samples in relation to the dimensions of the studied area.

Recent studies of the diatom flora of Colombia also show important differences between Andean and Amazonian regions that could be attributed to altitudinal gradients (Sala et al. 2008b).

Núñez-Avellaneda (2008) points out that aquatic studies in the Amazon region are concentrated in the Brazilian sector of the basin from Manaus to Tefé while in the higher sectors studies are scarce. This lack of information is more evident in relation to microalgae including diatoms. Although there are some diatom taxa described in classic, general and or ecological studies, the studies focused in morphology and taxonomy of diatoms from Amazonia are scarce. De Souza-Mosimann et al. (1997) and Ferrari et al. (2007) have studied diatoms from the Brazilian Amazon; Oliveira \& SteinitzKannan (1992) from Ecuadorian Amazonia; Sala et al. (1999, 2002a,b) from the Colombian Amazon and Sala et al. (2008a) also included information about Peruvian Amazon.

This paper is part of an integrated study of the diatom flora from the Colombian and Peruvian Amazon (Sala et al. 1999, 2002 a,b and 2008 a). In this opportunity the study area was enlarged. The studied sites comprise a large geographic area of the Amazonian basin in Colombia, and a sector shared by Colombia and Peru on the Putumayo River. Geological ancient areas related to the Guyanese Shield (Amauri Creek and Taraira I Lake), sectors related to the Tertiary Pebas Formation and the section of the Putumayo River (Gaviota and Bufeo Lakes and Porvenir River) and Recent Quaternary alluvial valley of the Amazon River (Lakes Yahuarcaca, Resaca and Tarapoto) were visited in Colombia. The new study area corresponds to a low area between the Andes and Amazonia with areas of higher antropic influence, but maintaining conditions of low mineralized waters.

Here we present those results related to the genera Encyonema, Encyonopsis and Gomphonema. Each taxon is described and its fine valve morphology compared with that of other specimens collected in other regions of the world. Also, we give information about geographic distribution and the environmental conditions of the sites where they were collected.

\section{MATERIALS AND METHODS}

Samples for this study were collected during 1993, 1994, 2001 and 2003 in lotic and lentic water bodies in the Colombian and Peruvian Amazon (Fig. 1). In Colombia the sampling sites are from the Amazonian-Andean region (a forest inundated creek); from the Amazon River (Tarapoto, Yahuarcaca III and Resaca Lakes) and from Japurá (Caquetá) River (Amauri Creek and Taraira I Lake). Sampling sites from Peruvian Amazon basin are placed at the Porvenir River, Gaviota and Bufeo Lakes (Putumayo or Içâ River).

Horizontal and vertical tows were made with a plankton net (mesh size $=24 \mu \mathrm{m})$ at different depths in the photic zone, and benthic diatoms were sampled by squeezing macrophytes. At each sampling station $\mathrm{pH}$, temperature, water transparency (Secchi disc) and conductivity using a combine probe YSI were registered (Table 1).

Samples were fixed with 6-8 \% formalin and were treated to eliminate organic matter following the method of Hasle \& Fryxell (1970) in Ferrario et al. (1995) and/or in a muffle furnace at $500{ }^{\circ} \mathrm{C}$ during 10 minutes. Samples for light microscopy (LM) were mounted in Hyrax or Naphrax. For scanning electron microscopy (SEM) samples were mounted on glass stubs and then metalized with gold- 


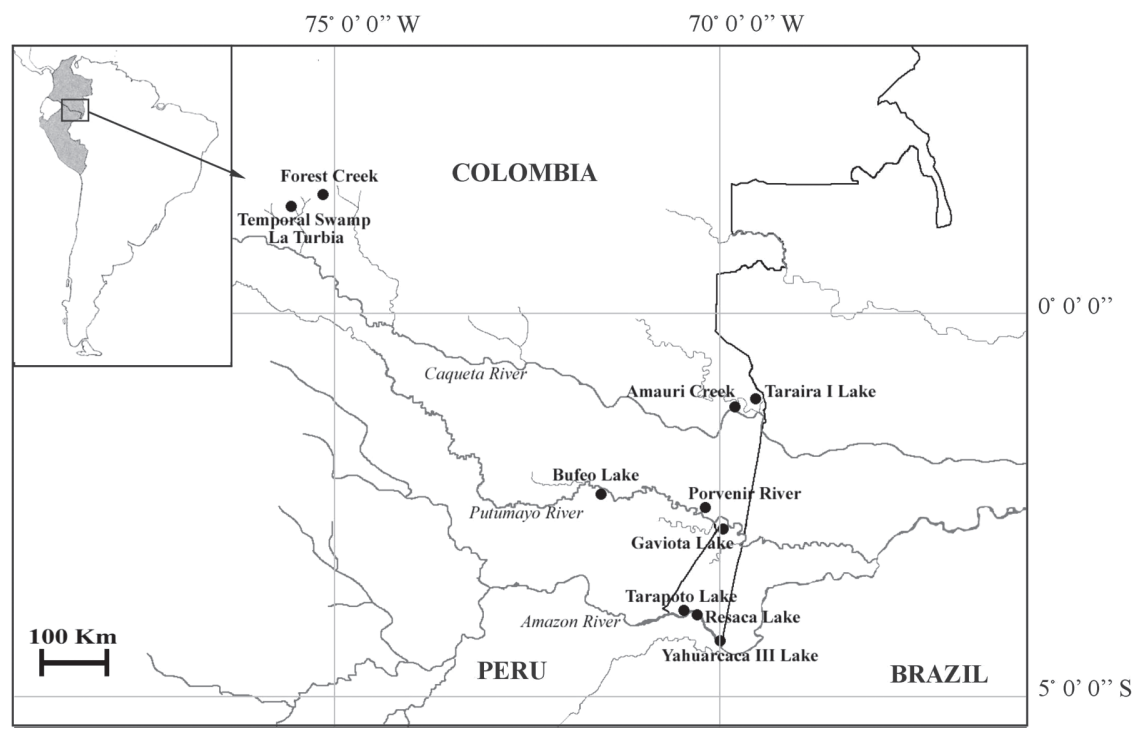

Fig. 1. Study area.

TABLE 1

Characteristics of the sampling sites. LPC: acronym of the Herbario del Departamento Cientifico Ficología del Museo de La Plata

\begin{tabular}{|c|c|c|c|c|c|}
\hline \multirow{2}{*}{ Sampling sites } & Sample & Temperature & $\mathrm{pH}$ & Conductivity & Transparency \\
\hline & LPC & $\left(\mathrm{C}^{\circ}\right)$ & & $\left(\mu \mathrm{S} \mathrm{cm}^{-1}\right)$ & $(\mathrm{cm})$ \\
\hline (1) Yahuarcaca III Lake & 5509 & 29.5 & 6.6 & 99 & 30 \\
\hline (2) Resaca Lake & 5507 & 30.0 & 7.4 & 180 & 105 \\
\hline (3) Tarapoto Lake & 5502 & 32 & 6.0 & 84 & 50 \\
\hline (4) Porvenir River & 5575 & 27.5 & 6.3 & 10 & 62 \\
\hline (5) Bufeo Lake & 5584 & 23 & 5.5 & 20 & 216 \\
\hline (6) Gaviota Lake & 5573 & 21 & 5.8 & 16 & 218 \\
\hline (7) Amauri Creek & 5512 & 26 & 4.8 & 10 & 60 \\
\hline (8) Taraira I Lake & 5514 & 28 & 4.8 & 5 & 160 \\
\hline (9) Forest Creek & 5610 & 26.5 & 5.1 & 8 & 45 \\
\hline
\end{tabular}

palladium. Observations were carried out with an Olympus $\mathrm{CH} 2 \mathrm{LM}$, a phase contrast Leica DM 2500 LM equipped with a Leica DFC420 digital camera and a Jeol TM 100 SEM and Jeol JSM- T100 SEM.

Materials were deposited in Ficoteca Amazónica at Universidad Nacional de Colombia (F.A.) and at Colección de Microorganismos Acuáticos Amazónicos, del Instituto Sinchi, Colombia (MICRA). Uncleaned and cleaned subsamples and permanent slides were also deposited at Herbario del Departamento Científico Ficología, Museo de Ciencias Naturales de La Plata, Argentina (LPC). Table 1 summarizes the physico-chemical information about samples. Other details of the samples and sampling stations are given below.

1. LPC 5509 (F.A. 300): Yahuarcaca III Lake, Departamento del Amazonas, Colombia. 
3-11-1994. Phytoplankton. 4²'’12.71'S, $69^{\circ} 57^{\prime} 03.05^{\prime \prime} \mathrm{W}$

2. LPC 5507 (F.A. 270): Resaca Lake, Mocagua Island, Colombia. 15/08/1994. Tycoplankton. $3^{\circ} 51^{\prime} 00.28^{\prime \prime} \mathrm{S}$,

$70^{\circ} 15^{\prime} 35.12$ " W

3. LPC 5502 (F.A. 159): Tarapoto Lake, Departamento del Amazonas, Colombia. 09-01-1993. Phytoplankton. 3०47'18.46" S, 70²5'30.55” W W

4. LPC 5575 (MICRA 0059): Porvenir River, Departamento del Amazonas, Colombia. 06-2001. Phytoplankton. 02²9'54" S, $70^{\circ} 11^{\prime} 14^{\prime \prime} \mathrm{W}$

5. LPC 5584 (MICRA 0100): Bufeo Lake, Provincia de Mainas, Perú. 6- 2001. Periphyton. $02^{\circ} 18^{\prime} 13^{\prime \prime} \mathrm{S}, 71^{\circ} 31^{\prime} 59^{\prime}$ " W

6. LPC 5573 (MICRA 0041): Gaviota Lake, Departamento del Amazonas, Colombia. 06-2001. Tycoperiphyton. 02 44'38' S, 69 $56^{\prime} 18^{\prime \prime} \mathrm{W}$

7. LPC 5512 (F.A. 312): Amauri Creek, Departamento del Amazonas, Colombia. 07-11-1994. Periphyton. 1 1010'50.19” N, 6948'21.80" W

8. LPC 5514 (F.A. 329): Taraira I Lake, Departamento de Vaupés, Colombia. 9-11-1994. Metaphyton. $1^{\circ} 05^{\prime} 09.88^{\prime \prime} \mathrm{N}$, 6931'18.33" W

9. LPC 5610: inundated forest creek, Departamento de Caquetá, Colombia. 11-2003. Periphyton. $1^{\circ} 38^{\prime} 01,46^{\prime \prime} \mathrm{N}$, $75^{\circ} 28^{\prime} 45,98^{\prime \prime} \mathrm{W}$.

The terminology used is that suggested in Anonymous (1975), Ross et al. (1979) and Barber \& Haworth (1981). For synonymy were followed Kusber \& Jahn (2003).

\section{RESULTS}

\section{Encyonema amazonianum nov. sp.}

(Figs. 2-7)

Valves asymmetric, dorsiventral, dorsal margin strongly convex, ventral margin slightly convex or straight. Ends rounded, rostrated. Striae uniseriated -with parallel lineolae- slightly radiate to the ends and finally parallel. One dorsal stigmoid, externally inconspicuous, is an unoccluded poroid at the end of the central stria; internally opened in a transversal slit just at the intermissio. Internally, the interstriae are not swollen to form transapical ribs; some areolae placed at the striae centre are reduced and rounded. Central area asymmetric, rounded on the dorsal side and continuous with the axial area moderately narrow on the ventral side. Raphe filiform. Externally slightly curved to the dorsal side of the valve, sinuous to the poles, central endings slightly expanded, terminal fissures hocked to the ventral margin. Internally the raphe has a small intermissio; distal endings with small helictoglossae, curved to the ventral margin, distant from the valve apex.

Dimensions: Length $30-34 \mu \mathrm{m}$, breadth $6-7 \mu \mathrm{m}, 1 / \mathrm{b} 4.5-5.5,11-12$ dorsal striae in $10 \mu \mathrm{m}$, 12-13 ventral striae in $10 \mu \mathrm{m}, 18-20$ striae in $10 \mu \mathrm{m}$ at the ends, $36-38$ areolae in $10 \mu \mathrm{m}$.

Studied material: Sample LPC 5575.

Type locality: Porvenir River, Colombia.

Valvae valde dorsiventrales, semi-lanceolatae, margine dorsali valde convexiore, margine ventrali convexo vel rectus, apicibus

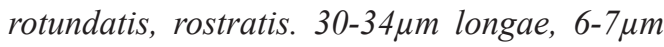
latae. Latere dorsale cum unum stigmoideum. Striae in latere dorsali in media parte modice radiantes ad polus versus paralellae, 18-20

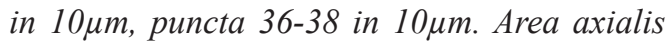
angusta, area centralis asymmetrica, orbicularis ad latere dorsale et lanceolata ad latere ventrali. Raphe excentrica, filiformis, paulo curvata margine ventralibus, terminis proximalibus (poris centralibus) at latus dorsalis inclinatis, fissuris distalibus in latus ventralis deflexis. Intermissio modice. Helictoglossae curvatis ad latere ventralis, distantis ab apex.

Typus: LPC 5575.

Locus typicus: Porvenir River.

When observed with LM, this species is similar to the Encyonema neogracile Krammer, its varieties and other related taxa: E. pseudogracile Krammer, E. pergracile 

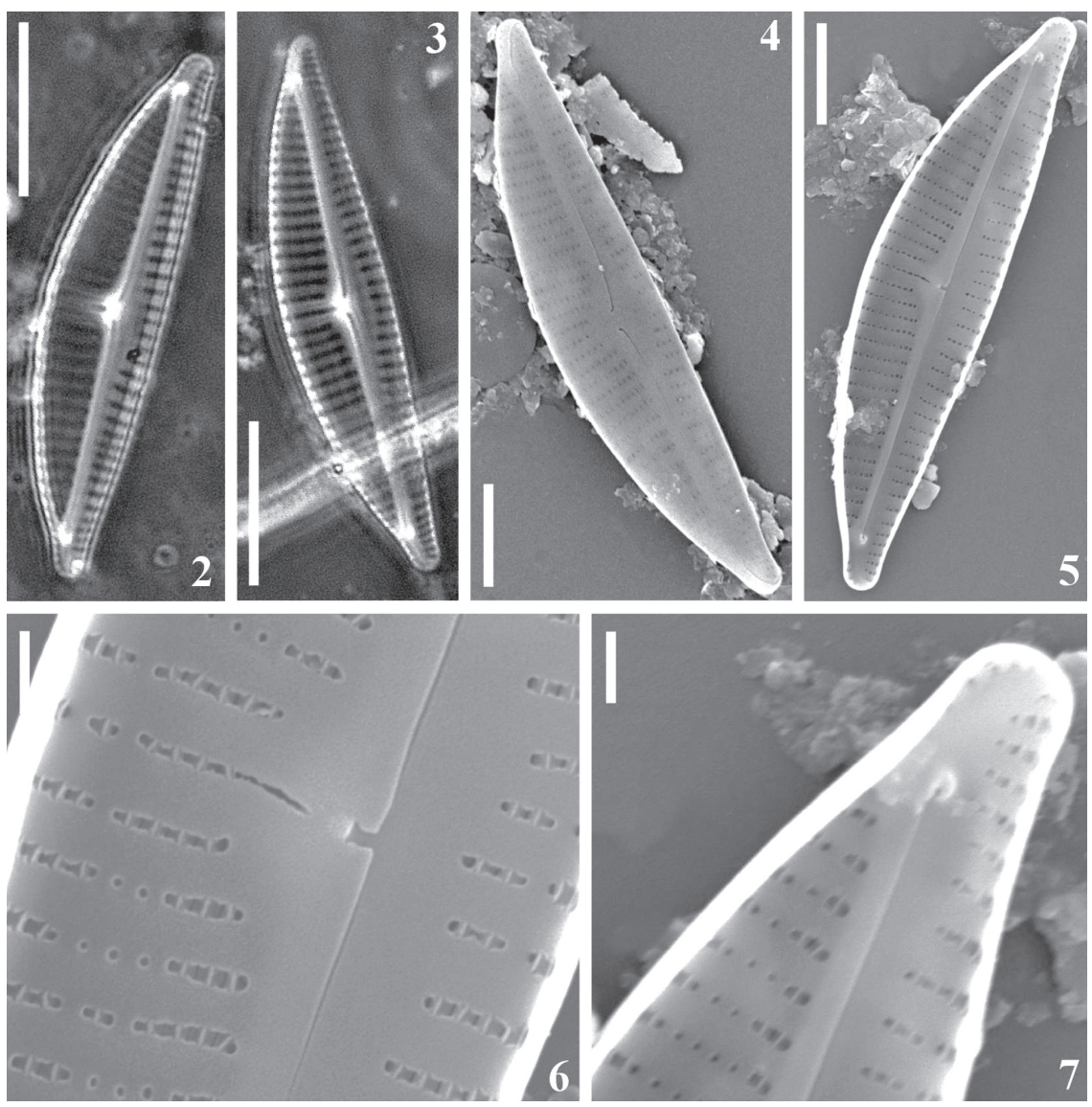

Figs. 2-7. Encyonema amazonianum. Figs. 2-3. LM, frustules in valve view. Figs. 4-7. SEM. Fig. 4. Valve in external view. Fig. 5. Valve in internal view. Fig. 6. Detail of the central part of the valve. Fig. 7. Detail of the apex. Scale bars $=10 \mu \mathrm{m}$ (Figs. 2,3); $5 \mu \mathrm{m}$ (Figs. 4,5); $1 \mu \mathrm{m}$ (Figs. 6-7).

Krammer and E. supergracile Krammer \& Lange-Bertalot (Krammer 1997a). It can be easily confused particularly with their smaller specimens as they have similar dimensions, 1/b ratio, and rostrated ends. Siever et al. 2005, point out that this group of related taxa needs careful further revision as they have overlapping characters. Nevertheless, the fine valve morphology of our specimens clearly differs from all the above mentioned in the absence of transapical costae and in the structure of the central striae with some areolae smaller and partially occluded. Besides, our specimens differ from E. pseudogracile in the narrow axial area, from $E$. neogracile in the intermissio with separate raphe ends and from E. supergracile in the smaller helictoglossae and the intermissio with raphe ends more distant.

This rare species was collected in a phytoplankton sample of a river with $\mathrm{pH} 6.3$, conductivity of $10 \mu \mathrm{Scm}^{-1}$, Secchi depth of $62 \mathrm{~cm}$ and temperature of $27.5^{\circ} \mathrm{C}$.

\section{Encyonema angustecapitatum Krammer,}

Biblioth. Diatomol. 37, p. 192, pl. 130:

Figs. 8-15 (1997). (Figs. 8-11)

Valves asymmetric, strongly dorsi-ventral, dorsal margin strongly convex, ventral margin straight and ends capitated. Striae uniseriated, slightly radiate all along the valve, sometimes parallel or convergent at the ends, areolae 

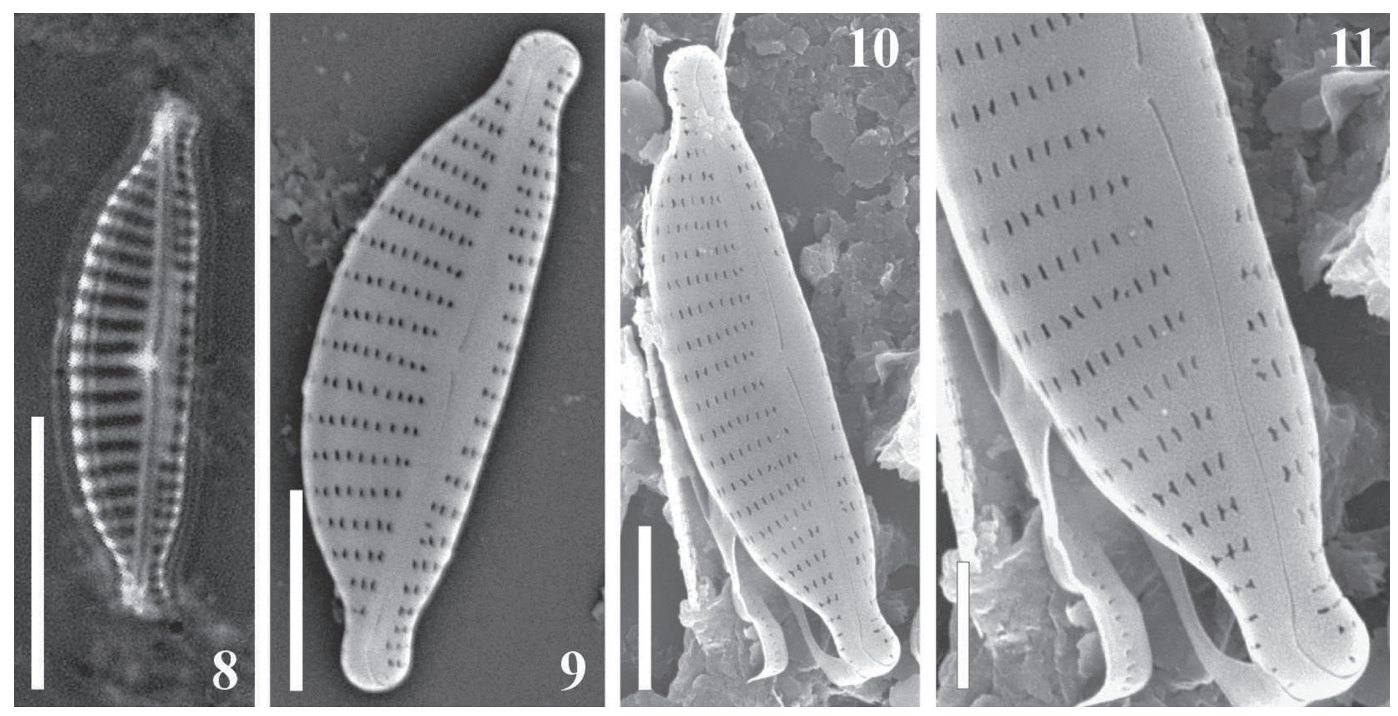

Figs. 8-11. Encyonema angustecapitatum. Fig. 8. LM, frustule in valve view. Figs. 9-11. SEM. Figs. 9-10. Valves in external view. Fig. 11. Detail of the valve. Scale bars $=10 \mu \mathrm{m}$ (Fig. 8); $5 \mu \mathrm{m}$ (Figs. 9-10); $2 \mu \mathrm{m}$ (Fig. 11).

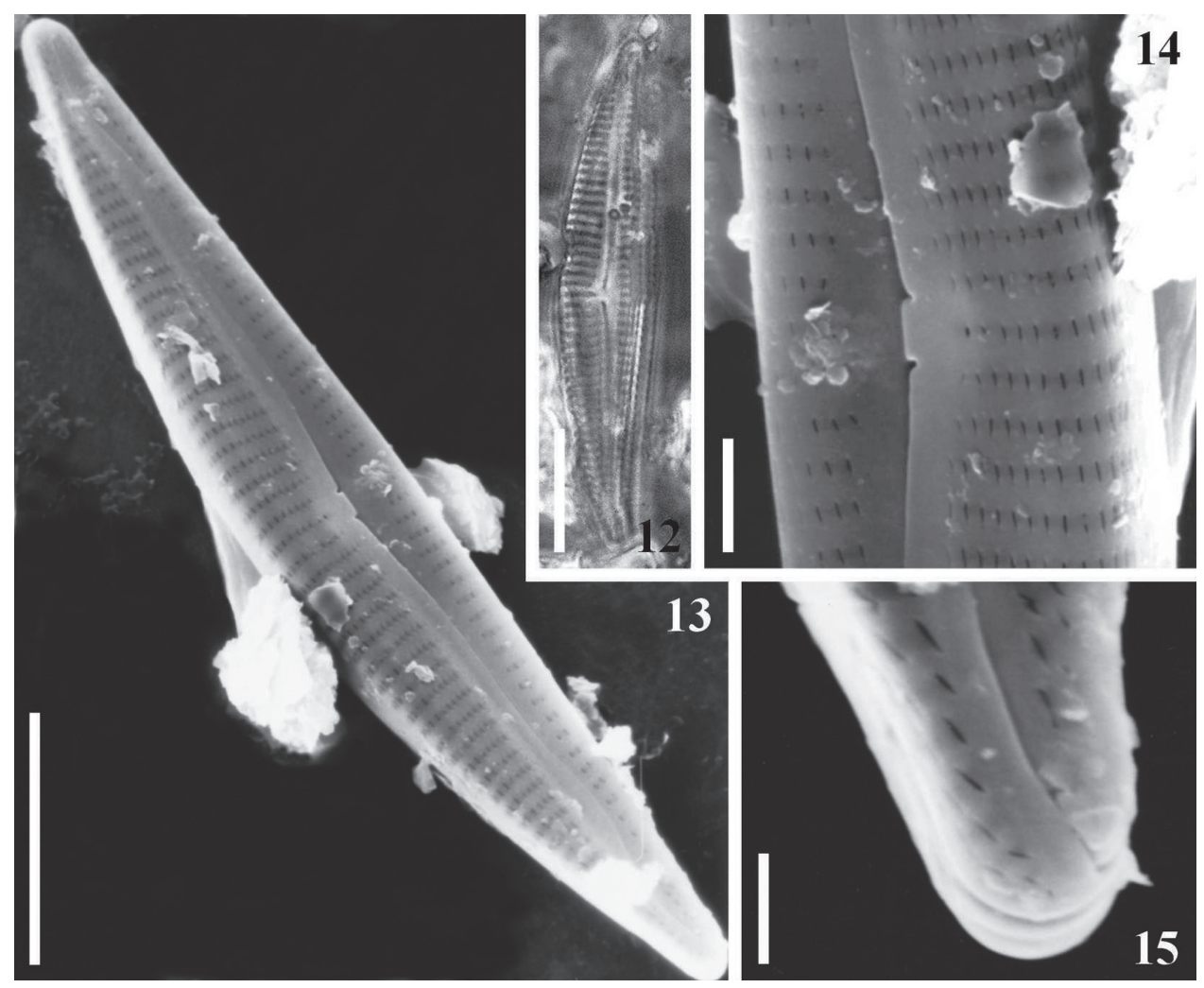

Figs. 12-15. Encyonema neogracile var. tenuipunctatum. Fig. 12. LM. general view. Figs. 13-15. SEM. Fig. 13. Valve in external view. Fig. 14. Detail of the central part of the valve. Fig. 15. Detail of the apex. Scale bars $=10 \mu \mathrm{m}($ Figs. 12-13); $2 \mu \mathrm{m}$ (Fig. 14); $1 \mu \mathrm{m}$ (Fig. 15). 
apically elongated, to the apices the areolae are more rounded or even transapically elongated. The Voigt fault is evident as a supernumerary areola on the ventral side of the valve. Axial area linear, slightly wide; central area asymmetric, on the dorsal side slightly differentiated from the axial area and widened at the ventral side. Stigmoid absent. Raphe filiform, moderately sinuous, curved to the dorsal side at the centre with slightly expanded ends, terminal fissures hooked to the ventral margin.

Dimensions: Length $16-20 \mu \mathrm{m}$, breadth $5 \mu \mathrm{m}, 1 / \mathrm{b} 3.5-4,10-12$ dorsal striae in $10 \mu \mathrm{m}$, 12-14 ventral striae in $10 \mu \mathrm{m}, 16-20$ striae in $10 \mu \mathrm{m}$ at the apices, 35-38 areolae in $10 \mu \mathrm{m}$.

Studied material: Sample LPC 5575.

Distribution: South American species. Type locality: Río Caroni, Venezuela (Krammer 1997b). Metzeltin \& Lange-Bertalot (1998) mentioned the species at the Río Tapajós (Brazilian Amazon) but the specimen illustrated with SEM (PL. 141, Fig. 6) does not correspond to this taxon, showing differences in the arrangement of the central dorsal striae and raphe fissures. Rumrich et al. (2000) mentioned it at San Lucior pond (Colombia) at $3000 \mathrm{~m}$ asl.

Observations: In the original description, Krammer (1997b) states that the central area is absent and continuous with the axial area, character considered diagnostic. The specimens in Rumrich et al. (2000) show a small central widening that comprises the two dorsal central striae. As in the studied specimens the dorsal central area is variable, we considered that this difference is not enough to separate them as a new taxon.

This species was collected in a phytoplankton sample of a river with $\mathrm{pH} 6.3$, conductivity of $10 \mu \mathrm{Scm}^{-1}$, Secchi depth of $62 \mathrm{~cm}$ and a temperature of $27.5^{\circ} \mathrm{C}$.

\section{Encyonema neogracile var. tenuipunctatum \\ Krammer, Biblioth. Diatomol. 36, p. 178, pl. 85: Figs. 1-6 (1997). (Figs. 12-15)}

Valves asymmetric, dorsiventral, dorsal margin convex, ventral margin concave or straight, slightly tumid at the centre. Rounded ends slightly elongated. Uniseriated striae, with parallel lineolae, more distant at the centre, slightly radiate to convergent at the ends. Stigmoid absent; the innermost pore of the dorsal central stria, round, internally opened in a transversal slit just at the intermissio. Central area absent, continuous with the moderately narrow axial area. Raphe filiform externally sinuous, slightly curved to the dorsal side of the valve; central endings expanded, distal fissures hocked to the ventral margin.

Dimensions: Length $31-46 \mu \mathrm{m}$, breadth $6.5-7 \mu \mathrm{m}, 1 / \mathrm{b} 4.6-7.2,12-15$ dorsal striae in $10 \mu \mathrm{m}, 12-14$ ventral striae in $10 \mu \mathrm{m}, 14-16$ striae in $10 \mu \mathrm{m}$ at the ends, 32-36 areolae in $10 \mu \mathrm{m}$.

Studied material: Samples LPC 5512, LPC 5575.

Distribution: Type locality: Laguna Santarem, Brazilian Amazon (Krammer 1997a). This species, is cited in the literature as cosmopolitan living in oligotrophic environments (Krammer 1997a), and is recorded for the first time in Colombia.

The species was collected in plankton and periphyton of lotic waterbodies with $\mathrm{pH}$ 4.86.3 , conductivity of $10 \mu \mathrm{Scm}^{-1}$, Secchi depth of $60-62 \mathrm{~cm}$ and a temperature of $26-27.5^{\circ} \mathrm{C}$.

\section{Encyonema venezolanum Krammer, Biblioth. Diatomol. 36, p. 162, pl. 19: Figs. 1-8 (1997). (Figs. 16-20)}

Cells strongly dorsiventral. Valves asymmetric, dorsal margin strongly convex, ventral margin straight slightly tumid at the centre; ends rounded. Striae uniseriated, lineolated, parallel and distant at the centre, slightly radiate and densely arranged at the ends; internally the interstriae strongly silicified with internal ribs. Central area absent, continuous with the axial area linear and moderately narrow. Stigmoid absent, the innermost areola of the central dorsal stria is externally rounded and internally opens as a small transverse slit. Raphe filiform sinuous, curved to the dorsal side at the centre with expanded ends, with distal fissures hocked 

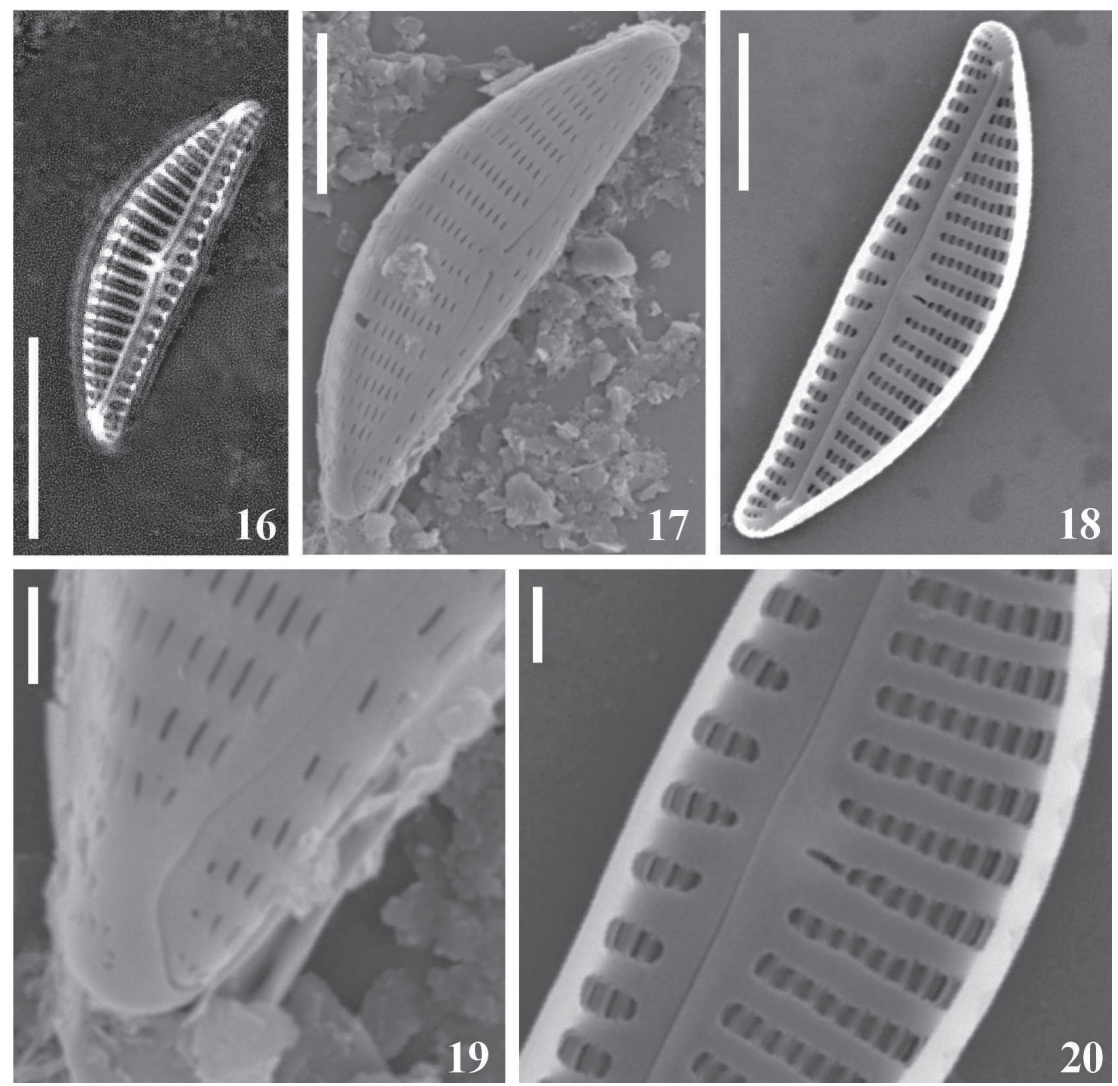

Figs. 16-20. Encyonema venezolanum. Fig. 16. LM, frustule in valve view. Figs. 17-20. SEM. Fig. 17. Valve in external view. Fig. 18. Valve in internal view. Fig 19. Detail of the apex. Fig. 20. Detail of the central part of the valve. Scale bars $=$ $10 \mu \mathrm{m}$ (Fig. 16); $5 \mu \mathrm{m}$ (Figs. 17-18); $1 \mu \mathrm{m}$ (Figs. 19-20).

to the ventral margin. Internally the raphe has no intermissio but has distal ends with small helictoglossae curved to the ventral margin.

Dimensions: Length, $18.5-21 \mu \mathrm{m}$, breadth, $4.5-5 \mu \mathrm{m}, 1 / \mathrm{b}, 3.8-4.1,11-12$ dorsal striae in $10 \mu \mathrm{m}, 11-12$ ventral striae in $10 \mu \mathrm{m}, 28-32$ areolae in $10 \mu \mathrm{m}$.

Studied material: Samples LPC 5502, LPC 5584.

Distribution: South America. Type locality: Río Kukenan, Venezuela (Krammer 1997a). This species is recorded in Colombia and Peru for the first time.

Observations: It is difficult to differentiate this taxon from E. silesiacum and E. minutum with LM as they have quite similar dimensions and valve outline, but it is easy to differentiate it among them with SEM as only the former has intermissio.

The species was collected in plankton and periphyton samples in two lakes with $\mathrm{pH}$ 5.5-6, conductivity of $20-84 \mu \mathrm{Scm}^{-1}$, Secchi depth of $50-216 \mathrm{~cm}$ and a temperature of $23-32{ }^{\circ} \mathrm{C}$.

Encyonema vulgare Krammer, Biblioth.

Diatomol. 36, p. 167, pl. 36: Figs. 4-10

(1997). (Figs. 21-26)

Synonym: Cymbella turgida sensu lato, pro parte.

Cells strongly dorsiventral. Valves asymmetric, dorsal margin strongly convex, ventral margin slightly tumid at the centre; ends rounded. Striae uniseriated, lineolate, slightly radiate 


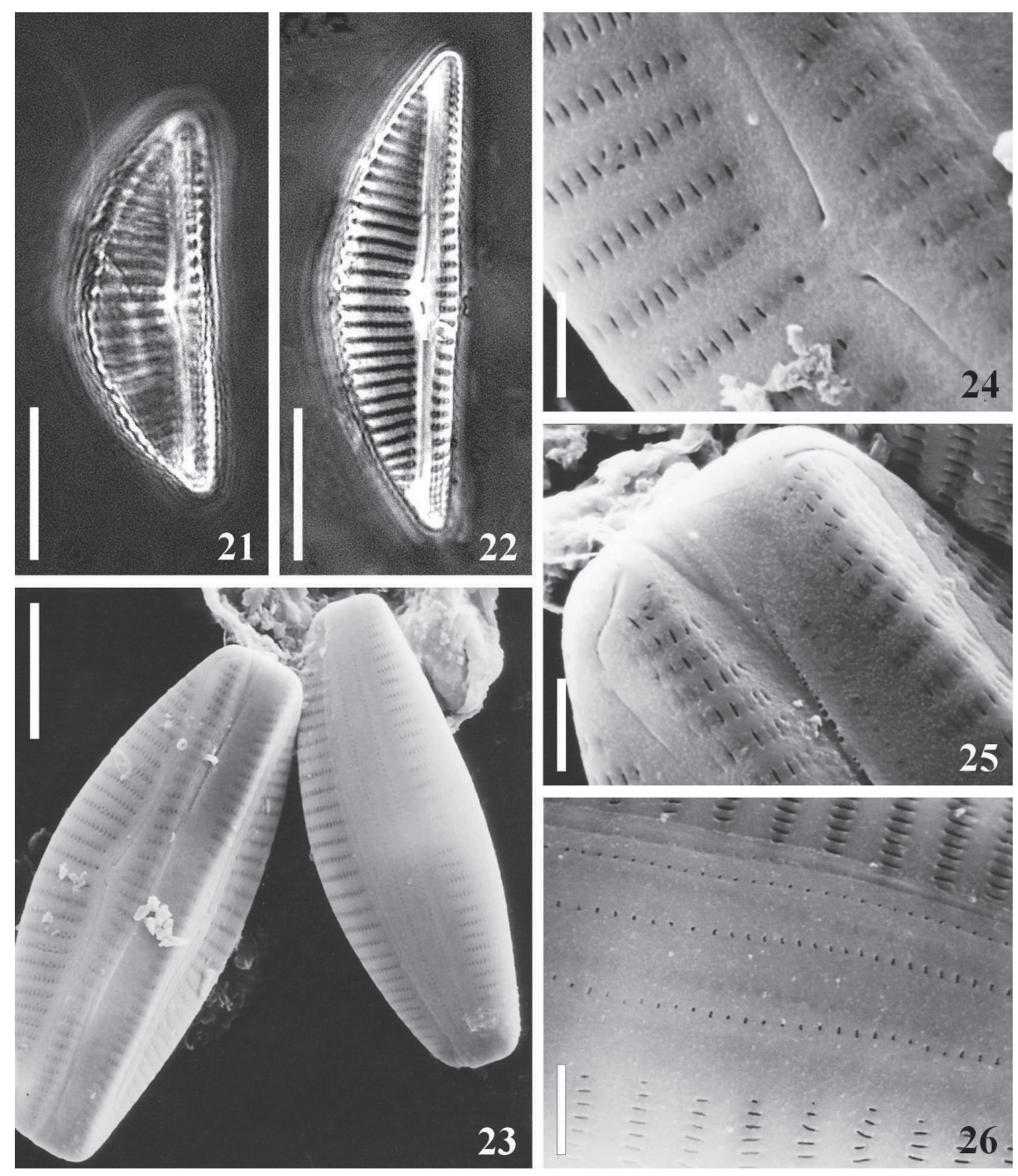

Figs. 21-26. Encyonema vulgare. Figs. 21-22. LM, frustule in valve view. Figs. 23-26. SEM. Fig. 23. Frustules in dorsal (right) and ventral (left) view. Fig. 24. Detail of the valve centre. Fig. 25. Detail of the apex of the frustule. Fig. 26. Detail of the cingulum in dorsal view. Scale bars $=10 \mu \mathrm{m}$ (Figs. 21-23); $2 \mu \mathrm{m}$ (Figs. 24-26).

all along the valve, central striae more distant; the striae run without interruption on the valve mantle. Central area continuous with the linear axial area. One dorsal stigmoid. Raphe with proximal ends expanded slightly curved to the dorsal side, terminal fissures hooked to the ventral margin. Girdle bands with small poroids.

Dimensions: Length $22-43 \mu \mathrm{m}$, breadth $7.5-11 \mu \mathrm{m}, 1 / \mathrm{b} 3.4,7-11$ dorsal striae in $10 \mu \mathrm{m}$, 9-12 ventral striae in $10 \mu \mathrm{m}, 29-35$ areolae in $10 \mu \mathrm{m}, 23$ in $10 \mu \mathrm{m}$ poroids of the girdle bands.
Studied material: Samples LPC 5502 and 5509.

Distribution: Cosmopolitan, recorded in Amazonia (Krammer 1997a) and Laguna Negra, Venezuela (Metzeltin \& Lange-Bertalot 1998). This species is mentioned in Colombia for the first time.

Observations: The studied specimens coincide in dimensions and general features with those described by Krammer (1997a) but it was not possible to compare the fine structure 
of the materials as the author illustrated them only with LM. It is difficult to differentiate this taxon from E. jemtlandicum Krammer 1997a (Figs 35: 1-9). E. jemtlandicum is wider (maximal $1 / b=5.3$ ) and more tumid.

The species was collected in plankton samples of a lake with $\mathrm{pH}$ 6-6.6, conductivity of $84-99 \mu \mathrm{Scm}^{-1}$, Secchi depth of $30-50 \mathrm{~cm}$ and a temperature of $29.5-32{ }^{\circ} \mathrm{C}$.
Encyonopsis frequentis Krammer, Biblioth. Diatomol. 37, p. 201-202, pl. 157: Figs. 10-11, pl. 158: Figs. 1-3, pl. 202: Figs. 1-6 (1997).

(Figs. 27-33)

Valves slightly dorsiventral, almost naviculoid, lanceolate with convex dorsal and ventral margins and capitated ends. Uniseriated striae with apically elongated poroids; radiate
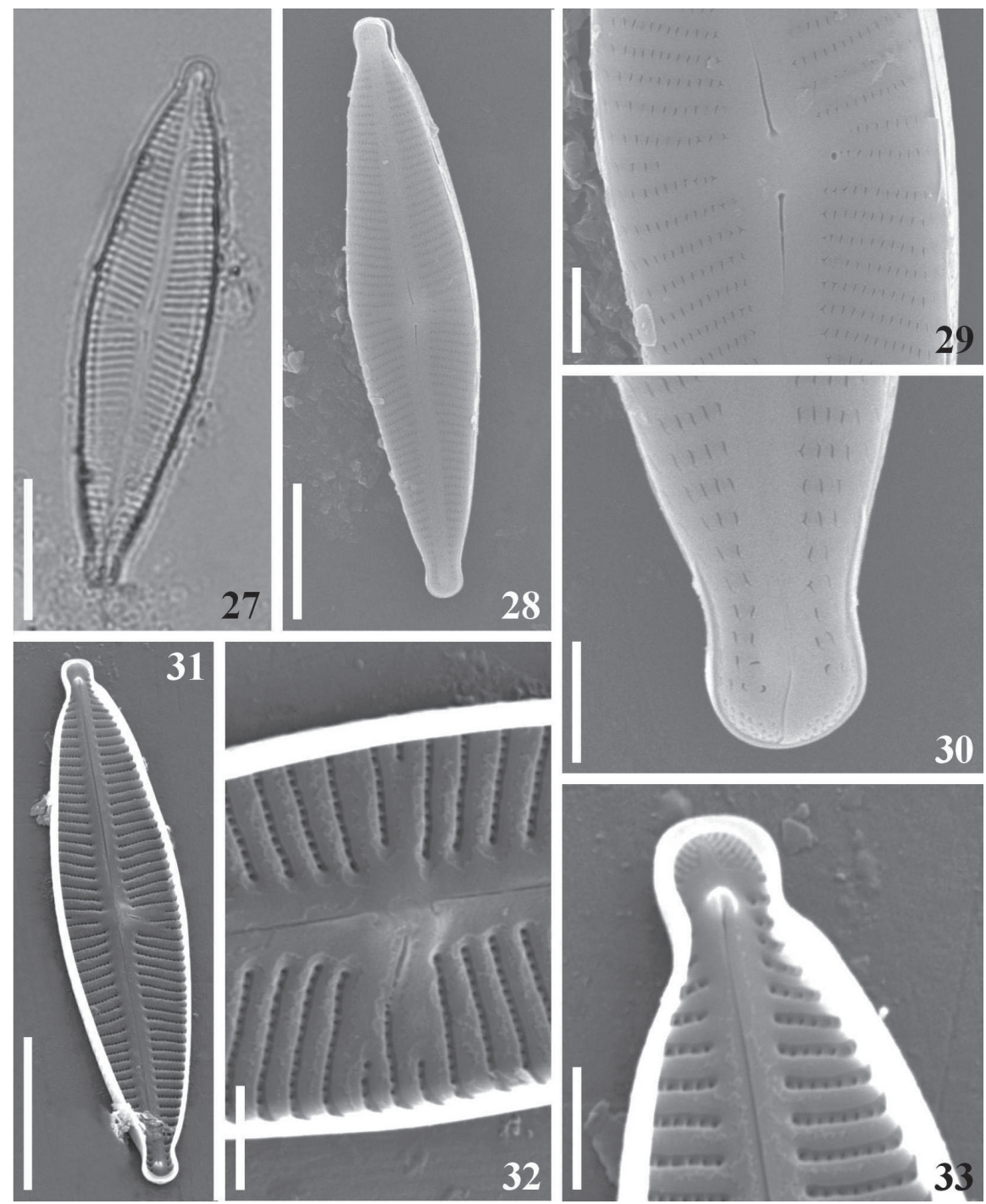

Figs. 27-33. Encyonopsis frequentis. Fig. 27. LM. frustule in valve view. Figs. 28-33. SEM. Fig. 28. Valve in external view. Fig. 29. Detail of the valve centre. Fig. 30. Detail of the apex. Fig. 31. Valve in internal view. Fig. 32. Detail of the valve centre. Fig. 33. Detail of the apex. Scale bars $=10 \mu \mathrm{m}$ (Figs. 27-28, 31); $2 \mu \mathrm{m}$ (Figs. 29-30, 32-33). 
and more distant at the valve centre, parallel to convergent at the valve ends; the striae are continuous at the mantle. Central area small, at both sides delimited by the irregularly shortened central striae. One dorsal stigmoid at the end of the central stria, with an external round poroid without occlusion, bigger than the other areolae and internally elongated as a slit oblique in relation to the transapical axis. Axial area linear, moderately wide. Raphe filiform sinuous, proximal ends expanded, smoothly curved to the dorsal side, distal fissures hooked to the ventral margin. Apical pore fields at both sides of the raphe fissure. Externally, proximal ends hooked towards the dorsal side and distal ones straight, ending at small helictoglossae.

Dimensions: Length $37.5-43 \mu \mathrm{m}$, breadth $8-9.5 \mu \mathrm{m}, 1 / \mathrm{b} 4.5-4.6,13.5-15$ striae in $10 \mu \mathrm{m}$, $40-41$ areolae in $10 \mu \mathrm{m}$.

Studied material: Samples LPC 5573, LPC 5575, LPC 5610.

Distribution: Type Locality: Río Kukenan, Venezuela (Krammer 1997b). This species is recorded in Colombia for the first time. Metzeltin \& Lange-Bertalot (1998) mentioned it at Lago Calado (Amazonia Brasilera).

Observations: The central area and central striae form a cruciform structure characteristic for the species (Krammer 1997b). This structure is visible at the external valve side of the studied specimens.

The specimens from Guyana described by Reichardt (1995) as Cymbella aequalis W. Smith, coincide with our material in the fine valve morphology, except for some slight morphometric differences (length 30-31 $\mu \mathrm{m}$, breadth $6-6.5 \mu \mathrm{m}, 14-17$ striae in $10 \mu \mathrm{m}, 39-42$ poroids in $10 \mu \mathrm{m})$.

The species was collected in periphyton and phytoplankton samples of lotic and lentic water bodies with $\mathrm{pH}$ 5.1-6.3, conductivity of $10-16 \mu \mathrm{Scm}^{-1}$, Secchi depth of $45-218 \mathrm{~cm}$ and temperature of $21-27.5^{\circ} \mathrm{C}$.
Gomphonema aff. affine Kützing,

Die. Kiesel. Bacill. oder Diat., p. 86, pl. 30,

Fig. 54 (1844). (Figs. 34-39)

Valves heteropolar, claviform, broader at the central area level. Apical and basal ends rounded. Striae uniseriated, occluded with reniform volae, slightly radiate and more distant at the centre, parallel to the valve ends. The Voigt fault is evident at the upper part of the valve in the presence of a reduced stria. The striae are continuous on the valve mantle. Raphe sinuous in external view, proximal ends straight, with elongated pores, distal fissure sinuous. There are round depressions irregularly distributed at the central area and the central portion of the axial area. A semicircular apical pore field with 5-6 rows of unoccluded small poroids can be observed at both side of the basal terminal fissure. Externally, the stigma is an unoccluded pore placed near the central stria. Central area asymmetric, unilateral, delimited by the shortening of the central stria opposite to the stigma.

Dimensions: length: $17.5-28 \mu \mathrm{m}$; breadth: 4.5-5.5 $\mu \mathrm{m}$; maximal $1 / \mathrm{b}: 4.2-5 ; 12-15$ striae in $10 \mu \mathrm{m} ; 30-32$ areolae in $10 \mu \mathrm{m}$.

Studied material: Sample LPC 5502.

Observations: The studied specimens are smaller than those described in Krammer \& Lange- Bertalot (1986) and Reichardt (1999). The dimensions given by these authors are: length: $30-100 \mu \mathrm{m}$, breadth: $7-12 \mu \mathrm{m}$, striae in $10 \mu \mathrm{m}$ : $9-13$ and length: $36-88$, breadth: $9-13,8-11$ striae in $10 \mu \mathrm{m}, 18-23$ poroids in $10 \mu \mathrm{m}$, respectively. Nevertheless, our material coincides in the type of striae and areolae and the presence of round marks at the axial and central areas. There are also differences in valve outline but this may be due to the smaller dimensions.

The species was collected in a phytoplankton sample of lake with $\mathrm{pH} 6$, conductivity 

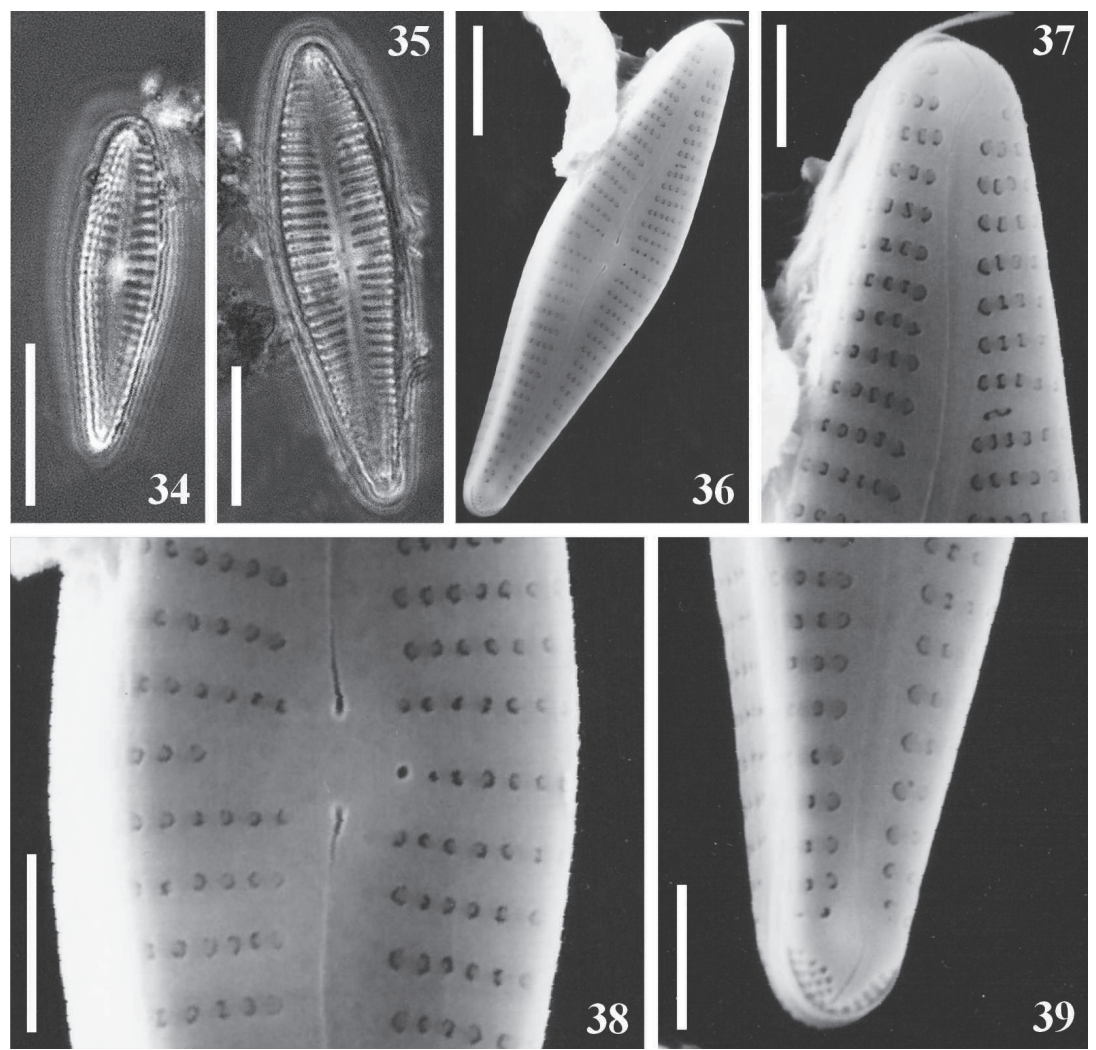

Figs. 34-39. Gomphonema aff. affine. Figs. 34-35. LM, frustules in valve view. Figs. 36-39. SEM. Fig. 36. Valve in external view. Fig. 37. Detail of the head-pole. Fig. 38. Detail of the valve centre. Fig. 39. detail of the foot-pole. Scale bars $=10 \mu \mathrm{m}$ (Figs. 34-35); $5 \mu \mathrm{m}$ (Fig. 36); $2 \mu \mathrm{m}$ (Figs. 37-39).

of $84 \mu \mathrm{Scm}^{-1}$, Secchi depth of $50 \mathrm{~cm}$ and temperature of $32^{\circ} \mathrm{C}$.

\section{Gomphonema augur var. sphaerophorum}

(Ehrenberg) Lange-Bertalot, Biblioth. Diatomol. 9, p. 43 (1985). (Figs. 40-41)

\section{Basionym: Gomphonema sphaerophorum} Ehr., Ber. Bekanntm. Verh. Königl. Preuss. Akad. Wiss. Berlin 1845, p. 78 (1845).

Valves heteropolar, apical and basal poles narrowly capitated. Maximum width at the central area. Striae uniseriated, parallel at the centre and slightly radiate to the poles; the two central striae more separated than the others; areolae occluded with reniform volae. Raphe sinuous in external view, proximal ends straight, expanded in a pore, terminal fissures sinuous. One stigma without occlusion placed at the end of the central stria. Central area asymmetric, slightly laterally expanded by the shortening of the central stria on the opposite side of the stigma.

Studied material: Samples LPC 5502, LPC 5507, LPC 5509, and LPC 5514.

Dimensions: Length $40-56 \mu \mathrm{m}$, breadth $12-15 \mu \mathrm{m}$, maximal $1 / \mathrm{b} 3.7,10-12$ striae in $10 \mu \mathrm{m}$ at the centre, $12-15$ in $10 \mu \mathrm{m}$ at the ends, 23 areolae in $10 \mu \mathrm{m}$.

Distribution: It is difficult to establish the distribution of the species as there have been confusions about the identity of this taxon, but it was reported without any doubt in Brazilian Amazon by Metzeltin \& Lange-Bertalot (1998) and at present is reported now for the first time in Colombia. 

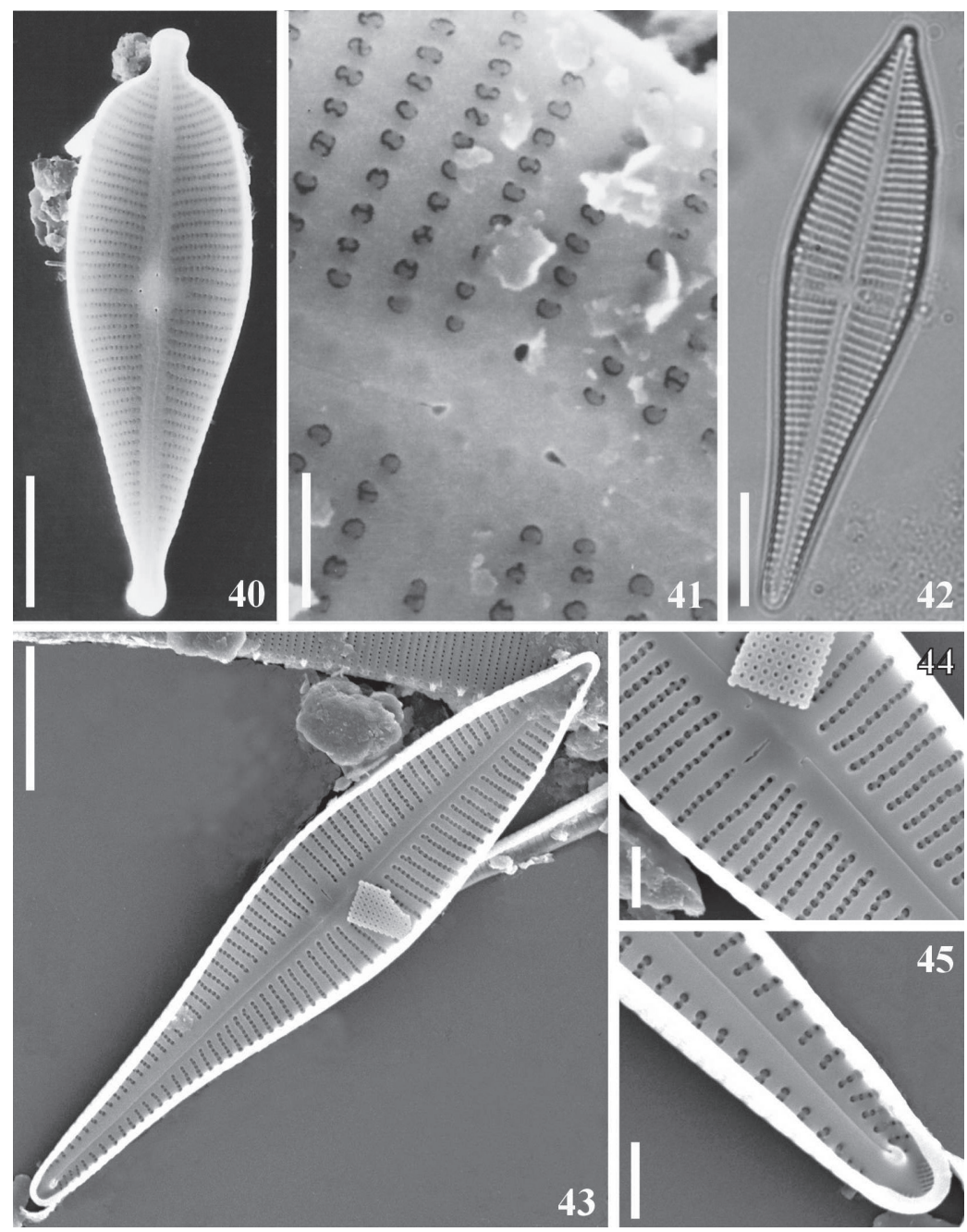

43

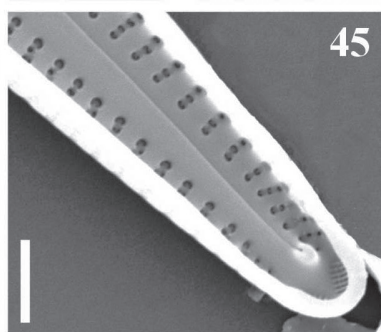

Figs. 40-41. Gomphonema augur var. sphaerophorum. SEM. Fig. 40. Valve in external view. Fig. 41. Detail of the valve centre. Figs. 42-45. Gomphonema contraturris. Fig. 42. LM, Frustule in valve view. Figs. 43-45. SEM. Fig. 43. Valve in external view. Fig. 44. Detail of the valve centre. Fig. 45. Detail of the foot-pole. Scale bars $=10 \mu \mathrm{m}$ (Figs. $40,42-44) ; 2 \mu \mathrm{m}$ (Figs. 41, 44-45).

The species is abundant in phytoplankton, tycoplankton and metaphyton samples from lakes with $\mathrm{pH}$ 4.8-7.4, conductivity of $5-180 \mu \mathrm{Scm}^{-1}$, Secchi depth of $30-160 \mathrm{~cm}$ and temperature of $28-32{ }^{\circ} \mathrm{C}$.

\section{Gomphonema contraturris Lange-Bertalot \& Reichardt in Lange-Bertalot, Bibliot.}

Diatomol. 27, p. 57-58, pl. 78: Figs. 2-9, pl. 79: Figs. 1-5 (1993). (Figs. 42-45)
Synonyms: Gomphonema acuminatun var. turris (Ehrenberg) Cleve sensu Fricke 1902; Gomphonema lanceolatum var. turris (Ehrenberg ex parte) Hustedt (1935) 1936, p. 166, Fig. 3: 23; Gomphonema lanceolatum f. turris (Ehrenberg ex parte) Hustedt 1938, p.437, Fig. 26: 8-11.

Valves heteropolar. Apical end apiculate, basal end narrowly rounded. Maximal width at the valve centre. Striae uniseriated, those 
at the centre (3) more distant than the others, parallel to slightly radiate all along the valve except at the basal pole where they are strongly radiate. Raphe slightly sinuous in internal view, proximal ends curved with L shape to the side of the stigma; distal ends slightly curved to the opposite side of the central ones, helictoglossae small. Apical pore fields semicircular. Internally the stigma is a transverse slit aligned with the median stria. Central area asymmetric, delimited by the shortening of the median stria on the side opposite to the stigma.

Dimensions: Length $54.5-75 \mu \mathrm{m}$, breadth $10.5-12 \mu \mathrm{m}$, maximal $1 / \mathrm{b}$ 4.9-6.2, 8-10 striae in $10 \mu \mathrm{m}$ at the centre, $12-13$ striae in $10 \mu \mathrm{m}$ at the poles, $25-28$ areolae in $10 \mu \mathrm{m}$.

Studied material: Sample LPC 5575.
Distribution: Type locality: Germany: München: Botanical Garden. Collector: Reichardt. This cosmopolitan species is now recorded in Colombia for the first time.

Observations: The species was abundant in a phytoplankton sample of a river with $\mathrm{pH}$ 6.3 , conductivity of $10 \mu \mathrm{Scm}^{-1}$, Secchi depth of $62 \mathrm{~cm}$ and temperature of $27.5^{\circ} \mathrm{C}$.

\section{Gomphonema neoapiculatum}

Lange-Bertalot, Reichardt \& Metzeltin in

Metzeltin \& Lange- Bertalot, Iconogr.

Diatomol. 5, p. 120, pl. 157: Figs. 6-9 (1998). (Figs. 46-51)

\section{Synonym: Gomphonema apiculatum} Ehrenberg sensu Reichardt 1995.
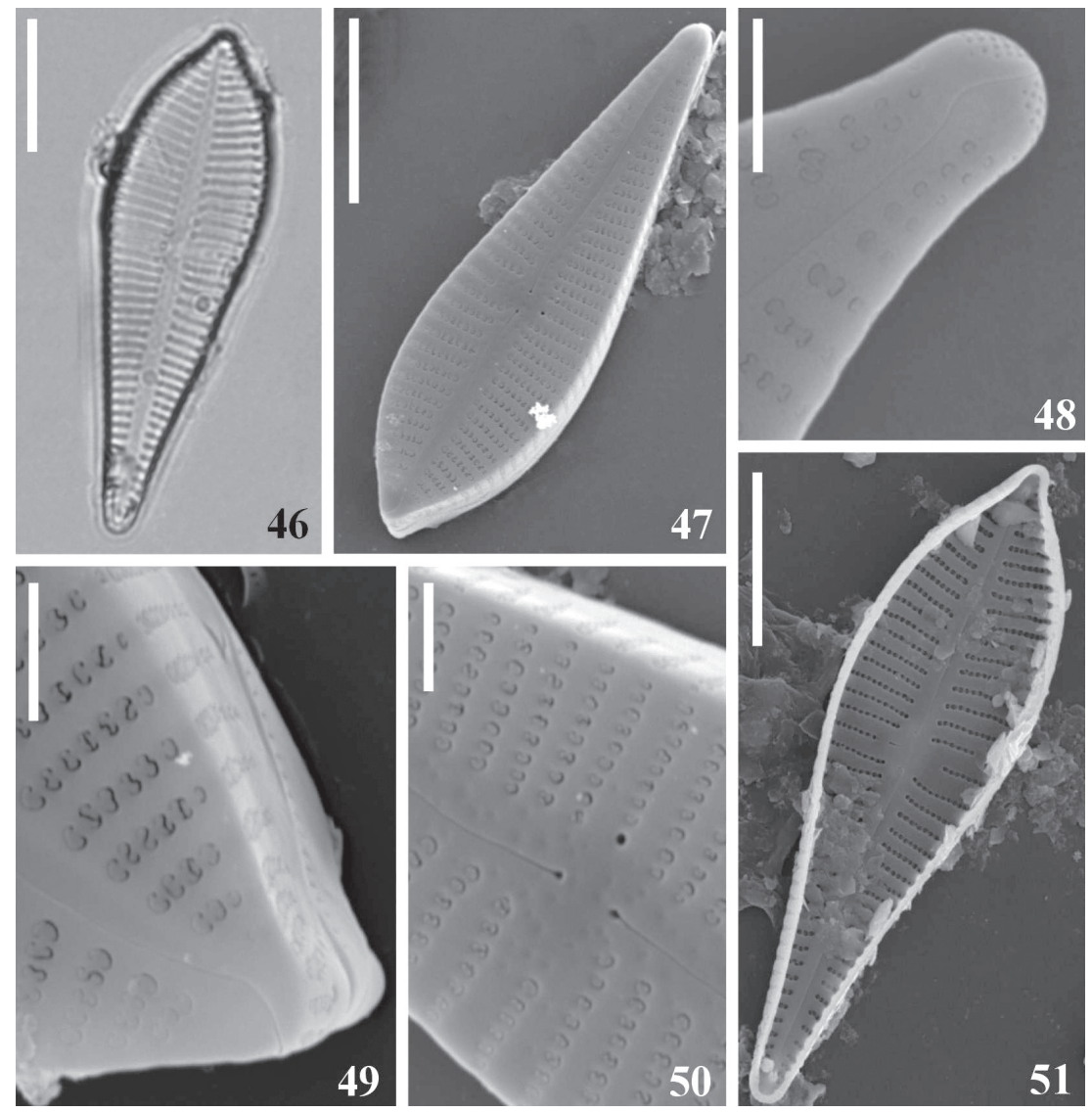

Figs. 46-51. Gomphonema neoapiculatum. Fig. 46. LM, Frustule in valve view. Fig. 47-51. SEM. Fig. 47. Valve in external view. Fig. 48. Detail of the foot-pole. Fig. 49. Detail of the head-pole. Fig. 50. Detail of the valve centre. Fig. 51. Valve in internal view. Scale bars $=10 \mu \mathrm{m}$ (Figs. 46-47, 51); $2 \mu \mathrm{m}$ (Figs. 48-50). 
Valves heteropolar; apical pole apiculate, basal pole rounded. Striae uniseriated with areoale occluded by reniform volae, slightly radiate alongside the valve. Foot-pole with triangular apical pore fields. Raphe sinuous in external view, proximal ends straight, expanded in pores, terminal fissure sinuous. Internally the raphe is straight, with proximal ends hooked to the side of the stigma; distal ends straight, helictoglossae small. Externally the stigma is an unoccluded pore placed at the end of the central stria; internally is a transapically elongated slit. Central area asymmetric delimited by the shortening of the central stria opposite to the stigma. At the central area and central portion of the axial area there are round depressions irregularly distributed.

Dimensions: Length $28-41 \mu \mathrm{m}$, breadth 9-11 $\mu \mathrm{m}$, maximal $1 / \mathrm{b} 3,8,10-13$ striae in $10 \mu \mathrm{m}$ at the centre, $12-15$ striae in $10 \mu \mathrm{m}$ at the ends, 24-30 areolae in $10 \mu \mathrm{m}$.

Studied material: samples LPC 5509, LPC 5512, LPC 5514, LPC 5575, and LPC 5584.

Distribution: Type locality: Río Essequibo, Guyana (Metzeltin \& Lange-Bertalot 1998). This species is recorded in Colombia, Peru and Amazonia for the first time.

Observations: The species was abundant in phytoplankton, periphyton and metaphyton samples collected in lentic and lotic waterbodies with $\mathrm{pH}$ 4.8-6.6, conductivity of $5-99 \mu \mathrm{Scm}^{-1}$, Secchi depth of $30-216 \mathrm{~cm}$ and temperature of $23-29.5^{\circ} \mathrm{C}$.

\section{DISCUSSION AND CONCLUSIONS}

Although high biodiversity of the Amazon region has been widely recognized, microalgae have been almost ignored and detail studies are needed (Núñez-Avellaneda 2008). Aquatic ecosystem research began in the middle of the twentieth century but concentrated at the Brazilian sector while in the Colombian sector studies started in the nineties and up to now thirty new algal species have been described. Results given in this paper add information about the diatom flora of the Amazon basin particularly about a large geographic area in Colombia, and a sector shared by Colombia and Peru on the Putumayo River. Some of the studied sites are pristine and visited for the first time for algal collection.

All the analyzed taxa are new records for the studied area as in previous papers of the Colombian Amazon were only analyzed two Gomphonema species: G. parvulum (Kützing) Kützing (Sala et al. 1999) and G. archaevibrio Lange-Bertalot \& Reichardt (Sala et al., 2002b) and the only diatoms publication available is from the Peruvian Amazon genus Urosolenia (Sala et al. 2008b). The genus Encyonema is mentioned for the first time in the Peruvian and Colombian Amazon and Encyonopsis in the Colombian Sector.

A new species, Encyonema amazonianum, was found in a phytoplankton sample collected at the Porvenir River, Departamento del Amazonas, Colombia. This species is similar to Encyonema neogracile, E. pseudogracile, E. pergracile and E. supergracile (Krammer 1997a) but clearly differs in its valve fine morphology. Besides morphological similarities this group of taxa has similar ecological requirements living in oligotrophic waterbodies and is well represented in the neotropics. E. neogracile is cosmopolitan but one morphotype of the var. neogracile and the var. teniupuctatum were collected in Brazil. On the other hand E. pseudogracile and E. supergracile were only registered in the type localities in Venezuela and in Colombia at $3500 \mathrm{~m}$ asl respectively.

Moreover, at Taropoto Lake were collected some Gomphonema specimens similar to $G$. affine. Although this species is considered cosmopolitan, the specimens found in the study area have morphometric differences that inhibit us to assign them reliably to this taxon. Many new neotropical taxa have been recently described, sometimes based on SEM analyses but sometimes based on the observation of few specimens with LM, generating more confusion. In this case we consider that the information about fine valve morphology of these materials is insufficient to generate a new taxon 
and prefer to maintain it as $G$. aff. affine until more material can be analyzed.

Gomphonema augur var. sphaerophorum, $G$. contraturris, Encyonema neogracile var. tenuipunctatum, E. vulgare and Encyonopsis frequentis, are recorded for the first time in Colombia; Encyonema venezolanum and Gomphonema neoapiculatum in Colombia and Peru and the latter is also mentioned for the first time in Amazonia.

The major part of the treated taxa is Neotropical, only Gomphonema contraturris, Encyonema neogracile var. tenuipunctatum and E. vulgare are cosmopolitan. On the other hand only Encyonema angustecapitatum was recorded before in South American highlands. Although this paper deals with few genera, these results support the ideas exposed in Metzeltin \& Lange-Bertalot (1998, 2007), Rumrich et al. (2000) and Sala et al. (2008b) about the existence of a particular diatom flora restricted to lowland tropical waters.

In the major part of the analyzed samples diatoms were scarce but it is striking the high species richness. The studied sites are waterbodies with high temperatures $\left(21-32^{\circ} \mathrm{C}\right)$, poor salt content (conductivity $5-180 \mu \mathrm{Scm}^{-1}$ ), low $\mathrm{pH}$ (4.8-7.4) and variable transparency (30-60 or $160-218 \mathrm{~cm}$ ) classified as Whyte waters type I or II (Núñez Avellaneda \& Duque 2001).

In the study area some species were restricted to one type of water and/or waterbody while others have a wide distribution. The most widespread taxon was Gomphonema neoapiculatum collected in lotic and lentic waterbodies with both types of water while Encyonopsis frequentis was collected in rivers and lakes but always in waters Type II influenced by Paleozoic and Tertiary geological formations with low $\mathrm{pH}$ (4.8-6.3) and conductivity $\left(8-20 \mu \mathrm{Scm}^{-1}\right)$. These waters also have low chlorophyll $a$ content (0.04-1.2 $\mu \mathrm{gl}^{-1}$ in Núñez-Avellaneda \& Duque 2001, Ricaurte et al. 2009).

Encyonema amazonianum, E. angustecapitatum, E. neogracile var. tenuipunctatum and Gomphonema contraturris were restricted to lotic waterbodies with White Waters Type II. Encyonema vulgare and Gomphonema aff. affine were the only ones collected in Lake Tarapoto with White waters Type I that corresponds to waterbodies from the Quaternary alluvial plain. In comparison with White waters Type II, this type has higher $\mathrm{pH}$ (6-7.4) and conductivity $\left(84-180 \mu \mathrm{Scm}^{-1}\right)$ and also higher trophic levels (chlorophyll a 2.3-23.6 $\mathrm{\mu gl}^{-1}$ sensu Duque et al. 1997; Núñez-Avellaneda 2005 and Ricaurte et al. 2009). Finally, E. venezolanum was restricted to lentic waterbodies with both water types.

\section{ACKNOWLEDGMENTS}

This research was held with the financial support of Universidad Nacional de La Plata; Instituto Amazónico de Investigaciones Científicas Sinchi, Beca de la Red Latinoamericana de Botánica RLB-04-P2-Tyler Prize 2004; Convención Ramsar, Instituto Nacional de Desarrollo (INADE) del Perú and Instituto Amazónico de Investigaciones (Imani) de la Universidad Nacional de Colombia, Sede Amazonia. The authors want to specially thank John Jairo Díaz who kindly prepared the map of the study area.

\section{RESUMEN}

La flora diatomológica de la Amazonia Colombiana y Peruana está mucho menos estudiada que la flora del sector brasilero. Se presentan los resultados de los géneros Encyonema, Encyonopsis y Gomphonema. Muestras de plancton y perifiton fueron colectadas en ambientes lóticos y lénticos de la región amazónica-andina, en los ríos Amazonas, Japurá y Porvenir durante 1993, 1994, 2001 y 2003. En cada estación de muestreo se realizaron mediciones de $\mathrm{pH}$, temperatura, transparencia del agua y conductividad. Las muestras fueron analizadas con microscopio óptico con contraste de fases y microscopio electrónico de barrido. Diez taxones son nuevos registros para el área; Encyonema en la Amazonia peruano-colombiana y Encyonopsis en el sector colombiano. Encyonema neogracile var. tenuipunctatum, E. vulgare, Encyonopsis frequentis, Gomphonema augur var. sphaerophorum y $G$. contraturris se reportan por primera vez en Colombia; Encyonema venezolanum y Gomphonema neoapiculatum en Colombia y Perú y la última también en la Amazonia. E. angustecapitatum fue previamente registrada en una laguna de altura en Colombia localizada a $3.000 \mathrm{msnm}$. Se describe una nueva especie, Encyonema amazonianum, colectada en el Río Porvenir, Amazonas, Colombia. 
Palabras clave: diatomeas, Encyonema, Encyonopsis, Gomphonema, Amazonia

\section{REFERENCES}

Anonymous. 1975. Proposals for a standardization of diatom terminology and diagnosis. Nova Hedw. Beih. 53: $323-354$

Barber, H. G. \& E.Y. Haworth. 1981. A guide to the morphology of the diatom frustule with a key to the British freshwater genera. Freshwater Biological Association 44, Ambleside, England.

De Souza-Mosimann, R. M., A.S. Tavares \& V.P. Freitas. 1997. Contribuição ao conhecimento da diatomoflórula do conteúdo estomacal de algumas espécies de peixes da Amazônia. I. Myleus sp. (pacú) do lago do Prato, AM, Brasil. Acta Amazonica 27: 9-26 (also available on-line: http://acta.inpa.gov.br/fasciculos/27-1/PDF/v27n1a02.pdf).

Duque, S. R., J. E. Ruiz, J. Gómez \& E. Roessler. 1997. Limnología. p. 71-134. In IGAC (ed.). Zonificación ambiental para el plan modelo Colombo - Brasilero (Eje Apaporis - Tabatinga: PAT). Editorial Linotipia, Bogotá, Colombia.

Ferrari, F., L. K. Procopiak, Y. B. Alencar \& T. A.V. Ludwig. 2007. Eunotiaceae (Bacillariophyceae) em igarapés da Amazônia Central, Manaus e Presidente Figueiredo, Brasil. Acta Amazonica 37: 1-16 (also available on-line: http://www.scielo.br/pdf/aa/v37n1/ v37n1a01.pdf).

Ferrario, M.E., E.A. Sar \& S.E. Sala. 1995. Metodología básica para el estudio del fitoplancton con especial referencia a las diatomeas, p. 1-23. In K. Alveal, M.E. Ferrario, E. Oliveira \& E.A. Sar (eds.). Manual de Métodos Ficológicos. Universidad de Concepción, Concepción, Chile.

Kociolek, P. \& S. Spaulding. 2000. Freshwater Diatom. Biography. Nova Hedw. 71: 1-19.

Krammer, K. 1997a. Die cymbelloiden Diatomeen. Eine Monographie der weltweit bekannten taxa. Teil 1. Allgemeines und Encyonema Part. Bibliotheca Diatomologica. Band 36. J. Cramer, Berlin-Stuttgart, Germany.

Krammer, K. 1997b. Die cymbelloiden Diatomeen. Eine Monographie der weltweit bekannten taxa. Teil 2. Encyonema Part., Encyonopsis and Cymbellopsis. Bibliotheca Diatomologica Band 37. J. Cramer, Berlin-Stuttgart, Germany.
Krammer, K. \& H. Lange Bertalot. 1986. Bacillariophyceae. In Süsswasserflora von Mittleuropa. Band 2, Teil 1. Naviculaceae. Gustav Fisher Verlag, Jena, Germany.

Lange-Bertalot, H. 1993. 85 New Taxa and much more the 100 taxonomic clarifications supplementary to Süßwasserflora von Mitteleuropa. Vol. 2/1-4. Bibliotheca Diatomologica. Band 27. J. Cramer, BerlinStuttgart, Germany.

Logares, R.E. 2006. Does the global microbiota consists of a few cosmopolitan species. Ecología austral 16: 85-90 (also available on-line: http:/www.scielo.br/ pdf/aa/v37n1/v37n1a01.pdf).

Metzeltin, D. \& H. Lange-Bertalot. 1998. Tropical diatoms of South America I. Iconographia Diatomologica. Annotated Diatom Micrographs. Vol. V. Koeltz Scientific Books, Königstein, Germany.

Metzeltin, D. \& H. Lange-Bertalot. 2007. Tropical diatoms of the South America II. Iconographia Diatomologica. Annotated Diatom Micrographs. Volume XVIII. Königstein, Germany.

Metzeltin, D., H. Lange-Bertalot \& F. García-Rodríguez. 2005. Diatoms of Uruguay. Iconographia Diatomologica. Volume XV. Königstein, Germany.

Núñez-Avellaneda, M. 2005. Fitoplancton de la cuenca del río Putumayo, Amazonia colombo-peruana. Tesis Magíster. Universidad Nacional de Colombia - Sede Amazonia. Leticia, Colombia.

Núñez-Avellaneda, M. 2008. Microalgas acuáticas: la otra escala de la biodiversidad en la Amazonia colombiana. Instituto Amazónico de Investigaciones Científicas, SINCHI. Bogotá, Colombia.

Núñez- Avellaneda, M. \& S.R. Duque. 2001. Estudio del fitoplancton en ambientes acuáticos de la Amazonia colombiana, p. 305-335. In C. Franky \& C. Zárate (eds.). Estudios en la Amazonia Colombiana IMANI MUNDO, Universidad Nacional de Colombia, Instituto Amazónico de Investigaciones. Editorial Unibiblos. Bogotá, Colombia.

Oliveira, P. E. \& M. Steinitz-Kannan. 1992. The diatom flora (Bacillariophyceae) of the Cuyabeno Faunistic Reserve, Ecuadorian Amazonia. Nova Hedw. 54: 515-552.

Reichardt, E. 1995. Die Diatomeen (Bacillariophyceae) in Ehrenbergs material von Cayenne, Guyana Gallica (1843). Iconographia Diatomologica. Volume I. Koeltz Scientific Books, Königstein, Germany. 
Reichardt, E. 1999. Zur revision der gattung Gomphonema. Iconographia Diatomologica. Volume VII. Koeltz Scientific Books, Königstein, Germany.

Ricaurte, L. F., M. Núñez-Avellaneda, J. C. Alonso \& J. C. Donato. 2009. Inventario y clasificación de humedales en el piedemonte amazónico colombiano: una guía para inventarios a nivel regional. Instituto Amazónico de Investigaciones Científicas, SINCHI y Convención de Ramsar. Bogotá, Colombia.

Ross, R., E.J. Cox, D.G. Karayeva, D.G. Mann, T.B. Paddock, R. Simonsen \& P.A. Sims. 1979. An emended terminology for the siliceous components of the diatom cell. Nova Hedw. 64: 513-533.

Rumrich, U., H. Lange-Bertalot \& M. Rumrich. 2000. Diatomeen der Anden von Venezuela bis Patagonien/ Feuerland Und zwei weitere Beiträge. Iconographia Diatomologica. Volume IX. Königstein, Germany.

Sala, S., S.R. Duque, M. Núñez-Avellaneda \& A.A. Lamaro. 1999. Nuevos registros de diatomeas (Bacillariophyceae) de la Amazonia Colombiana. Caldasia 21: 26-37.

Sala, S., S.R. Duque, M. Núñez-Avellaneda \& A.A. Lamaro. 2002a. Diatoms from the Colombian Amazonia. Cryptog. Algol. 23: 75-99.

Sala, S., S.R. Duque, M. Núñez-Avellaneda \& A.A. Lamaro. 2002b. Diatoms from the Colombian Amazon: some species of the genus Eunotia (Bacillaryophyceae). Acta Amazon. 32: 589-603 (also available on-line: http://acta.inpa.gov.br/fasciculos/32-4/PDF/ v32n4a05.pdf).

Sala, S.E., M. Núñez-Avellaneda \& A.A. Vouilloud. 2008a. Ultrastructure of the frustule of Urosolenia species from the colombian and peruvian Amazon: U. delicatissima nov. spec., $U$. amazonica nov. spec. and $U$. braunii (Hustedt). Diat. Res. 23: 159-169.

Sala, S.E., J.J. Ramirez \& Y. Plata Diaz. 2008b. Diatoms from lentic and lotic systems in Antioquia, Chocó and Santander Departments in Colombia. Rev. Biol. Trop. 56: $1159-1178$.

Siver, P.A., P.B. Hamilton, K. Stachura-Suchoples \& J.P. Kociolek. 2005. Diatoms of North America. The freshwater Flora of Cape Cod. Iconographia Diatomologica. Vol. XIV. Königstein, Germany.

\section{INTERNET REFERENCES}

Kusber, W.H. \& R. Jahn. 2003. Annotated list of diatom names by Horst Lange-Bertalot and co-workers. Botanic Garden and Botanical Museum BerlinDahlem, Free University Berlin, Berlín, Alemania. (Consultado: 2/10/2008, http://www.algaterra.org/ Names_Version 3.0.pdf). 